\title{
GaPt Supported Catalytically Active Liquid Metal Solution Catalysis for Propane Dehydrogenation-Support Influence and Coking Studies
}

Narayanan Raman, Moritz Wolf, Martina Heller, Nina Heene-Würl, Nicola Taccardi, Marco Haumann, Peter Felfer, and Peter Wasserscheid*

Cite This: ACS Catal. 2021, 11, 13423-13433

Read Online

ABSTRACT: Supported catalytically active liquid metal solutions (SCALMS) of $\mathrm{Pt}$ in $\mathrm{Ga}(2$ at.-\% $\mathrm{Pt}$ ) were studied in the temperature range of 500 to $600{ }^{\circ} \mathrm{C}$ for propane dehydrogenation. A facile synthesis procedure using ultrasonication was implemented and compared to a previously reported organo-chemical route for gallium deposition. The procedure was applied to synthesize GaPt-SCALMS catalyst on silica $\left(\mathrm{SiO}_{2}\right)$, alumina $\left(\mathrm{Al}_{2} \mathrm{O}_{3}\right)$, and silicon carbide $(\mathrm{SiC})$ to investigate the effect of the support material on the catalytic performance. The $\mathrm{SiC}$ based SCALMS catalyst showed the highest activity, while $\mathrm{SiO}_{2}$-based SCALMS showed the highest stability and lowest cracking tendency at higher temperatures. The selectivity toward propene for the $\mathrm{SiO}_{2}$-based catalyst remained above $93 \%$ at $600{ }^{\circ} \mathrm{C}$. The catalysts were analyzed for coke content after use by temperature-programmed oxidation (TPO)

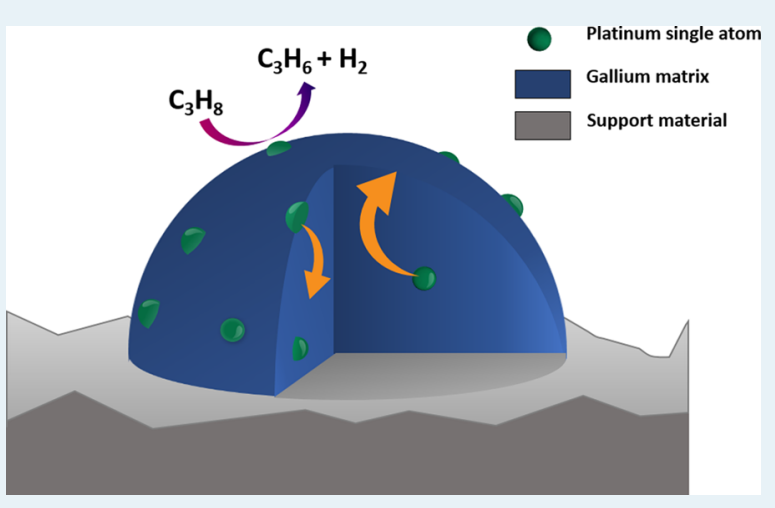
and Raman spectroscopy. While the $\mathrm{SiC}$ - and $\mathrm{SiO}_{2}$-supported SCALMS systems showed hardly any coke formation, the $\mathrm{Al}_{2} \mathrm{O}_{3}$-supported systems suffered from pronounced coking. SEM-EDX analyses of the catalysts before and after reaction indicated that no perceivable morphological changes occur during reaction. The SCALMS catalysts under investigation are compared with supported $\mathrm{Pt}$ and supported GaPt solid-phase catalyst, and possible deactivation pathways are discussed.

KEYWORDS: supported liquid catalysis, SCALMS, gallium, platinum, dehydrogenation, coking

\section{INTRODUCTION}

The concept of supported catalytically active liquid metal solutions (SCALMS) was recently introduced for hightemperature catalysis. ${ }^{1}$ Herein, a low melting and typically catalytically inactive metal (e.g., Ga) is doped with a small amount of a catalytically active metal (e.g., Pd, Rh, Pt), ${ }^{1-4}$ and the resulting bimetallic alloy is deposited onto a porous support. The SCALMS material concept is shown schematically in Figure 1. In the SCALMS concept, the supported alloy is fully liquid at reaction temperatures. Note in this context that the melting point of these alloys is strongly dependent on the concentration and nature of the precious metal added. While pure gallium melts around $30{ }^{\circ} \mathrm{C}$, addition of small amounts of another metal can increase the melting point of the resulting alloy to temperatures of $300{ }^{\circ} \mathrm{C}$ and beyond. ${ }^{5}$

The precious metal is fully dissolved in the liquid Ga matrix under reaction conditions and is highly mobile, forming single atom sites at the liquid alloy-gas interface. ${ }^{6}$ The concept provides a unique approach to achieve robust single-atom catalysis. $^{7-9}$ The single atom nature of the active site was first demonstrated by DFT calculation for GaPd systems and supported for $\mathrm{GaRh}^{2}$ and $\mathrm{GaPt}^{3}$ systems using infrared reflection-absorption spectroscopy (IRAS). ${ }^{1,3}$ In short, the outer layer of the liquid alloy droplets is typically depleted in atoms of the catalytically active metal. ${ }^{10}$ In the presence of the reactants, however, the catalytically active metal atoms appear as single atoms at the gas-liquid metal interface to provide their catalytic reactivity to the system. Upon desorption of the formed products, the active metal atoms dive back into the bulk of the Ga-rich droplets resulting in a self-regenerating process of the catalytically active interface. ${ }^{11}$

SCALMS systems were successfully applied for butane and propane dehydrogenation, where the avoidance of rapid deactivation by coking is the primary challenge to realize effective catalytic materials. ${ }^{12-15}$ In the state of the art, the

Received: April 28, 2021

Published: October 21, 2021 


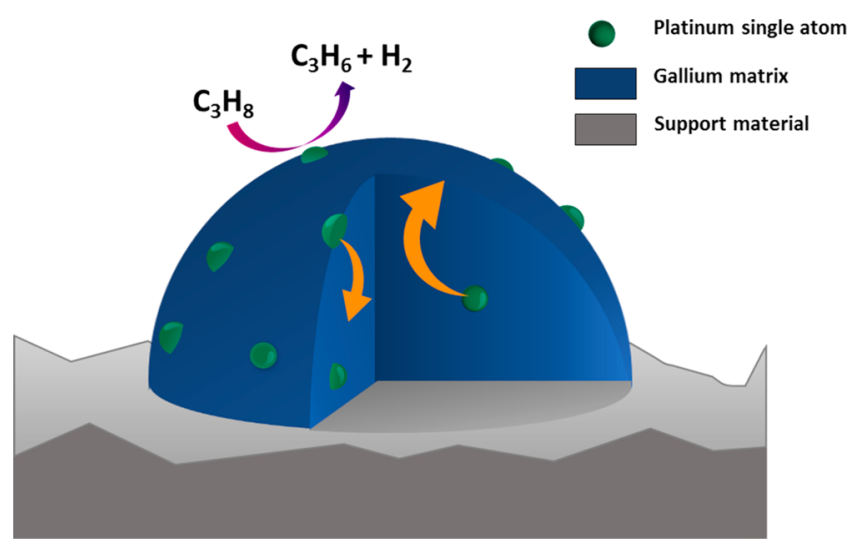

Figure 1. Schematic representation of GaPt-SCALMS catalysts for propane dehydrogenation. Single Pt atoms are shown in green within the blue Ga matrix. The dynamics of the system at high temperature is indicated by the trajectory of $\mathrm{Pt}$ moving from the bulk (orange arrows) to the surface and back.

catalysts are periodically regenerated by oxidation with air, which increases the complexity of the technical operation. ${ }^{16}$ Alternatively, oxygen is cofed into the reactor to reduce coking, but this causes a loss of selectivity due to partial combustion of propane. ${ }^{17-19}$

The special nature of the active sites in SCALMS systems has been shown to reduce coke formation and to enhance catalyst lifetime under the harsh conditions of high-temperature dehydrogenation reactions. ${ }^{1,2}$ The claim is that coke formation on the Ga-stabilized, single atom precious metal sites that form at the gas-alloy interface of SCALMS is suppressed because of the absence of vicinal catalyst sites required for the coke formation process. Note, however, that also the bare support surface is able to form coke from relevant precursor molecules, such as the products formed in alkane dehydrogenation.
In this contribution, we present a new, easy, and scalable approach to prepare gallium decorated supports and SCALMS systems. Our new methodology represents a very attractive alternative to the so far applied synthesis of SCALMS by impregnation with the very air sensitive compound $\left(\mathrm{Et}_{3} \mathrm{~N}\right)$ $\mathrm{GaH}_{3}$ as precursor for the $\mathrm{Ga}$ metal, obtained after thermal treatment, followed by galvanic displacement to introduce the catalytically active metal (in the following referred to as the chemical route). Our new approach builds on the fact that liquid metals, such as gallium, can be ultrasonicated to form colloidal dispersions in appropriate solvents. ${ }^{20-23}$ The nanoand microdroplets obtained in this way can then be easily transferred to any support. Therefore, in this study, this method is applied to produce Ga-decorated support materials. The introduction of the catalytically active metal is achieved subsequently by galvanic displacement (Figure 2). ${ }^{24} \mathrm{We}$ compare the catalytic performance of GaPt-SCALMS systems prepared by the organo-chemical route with materials obtained from the newly developed ultrasonication method. Moreover, we use the newly developed preparation method for SCALMS materials to systematically study support effects in GaPtSCALMS systems for propane dehydrogenation. In detail, we present the catalytic performance of SCALMS systems on silica $\left(\mathrm{SiO}_{2}\right)$, alumina $\left(\mathrm{Al}_{2} \mathrm{O}_{3}\right)$, and silicon carbide $(\mathrm{SiC})$ supports.

\section{MATERIALS AND METHODS}

All chemicals were used as received. SCALMS preparation was carried out using standard Schlenk techniques using $\mathrm{Ar}$ (99.999\% purity, Linde Gas) as inert gas. Three different support materials, namely, alumina (Sigma-Aldrich; grade: Brockmann I, activated, standard; particle size: $0.05-0.15 \mathrm{~mm}$; BET surface area: $\left.155 \mathrm{~m}^{2} \mathrm{~g}^{-1} ; \mathrm{pH}: 7.0 \pm 0.5\right)$, silica micropsheres (Sigma-Aldrich; $0.06-0.17 \mathrm{~mm}$ ), and silicon carbide (SICAT, France; $\beta$-SiC; pellet size: $3 \mathrm{~mm}$ ), were applied in this study.

Preparation of Catalysts by the Ultrasonication Method. The supported Ga catalysts were prepared by

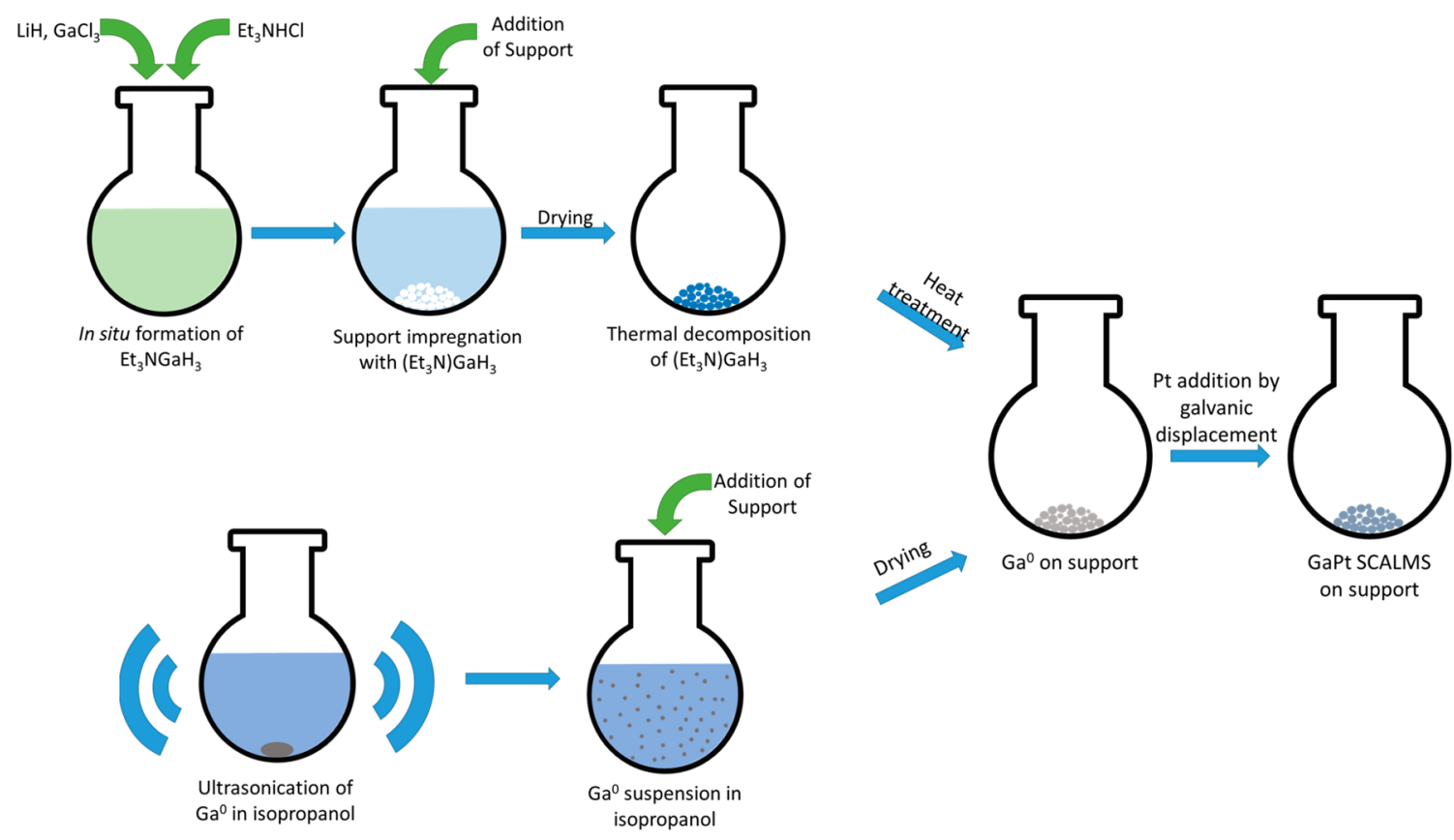

Figure 2. Schematic representation of the GaPt-SCALMS synthesis using the chemical route and the newly developed ultrasonication method. 
physical deposition of metallic gallium on the different porous supports. A $6 \mathrm{~mm}$ Gallium nugget (5N, Alpha-Aesar) of approximately $0.8-0.9 \mathrm{~g}$ was dispersed in $100 \mathrm{~mL}$ isopropanol via ultrasonication (Branson 450 sonicator, $80 \%$ intensity for $10 \mathrm{~min}$ ) at $40{ }^{\circ} \mathrm{C}$ and this created a fine emulsion of liquid Ga droplets. After sonication, the emulsion was added to the required amount of support material to achieve a 5\% loading of $\mathrm{Ga}$ on support. Then, the solvent was slowly evaporated in a rotary evaporator at $50{ }^{\circ} \mathrm{C}$. The obtained solid was calcined at $450{ }^{\circ} \mathrm{C}$ overnight.

The GaPt-SCALMS catalysts were prepared via galvanic displacement. A solution of hexachloroplatinic acid in water (2-3 $\left.\mathrm{mg} \mathrm{Pt} \mathrm{mL}^{-1}\right)$ was added to a suspension of $10 \mathrm{~g}$ of the respective Ga-decorated support in $50 \mathrm{~mL}$ of isopropanol targeting a desired $\mathrm{Ga}$ to $\mathrm{Pt}$ ratio of 45 (vide infra). The solvent was evaporated at $50{ }^{\circ} \mathrm{C}$ in a rotary evaporator. The resulting SCALMS was calcined at $450{ }^{\circ} \mathrm{C}$ overnight.

Additionally and for comparison, a GaPt SCALMS catalyst was also prepared on $\mathrm{Al}_{2} \mathrm{O}_{3}$ using the chemical route as described by Bauer et al. ${ }^{3}$ These platinum-decorated materials were also prepared by impregnation of the relevant support material with a hexachloroplatinic acid solution with subsequent drying at $50{ }^{\circ} \mathrm{C}$ and calcination at $450{ }^{\circ} \mathrm{C}$ overnight.

Metal Content Analysis. The Ga and Pt loadings of the prepared catalysts were determined by inductively coupled plasma atomic emission spectroscopy (ICP-AES) using a Ciros $\mathrm{CCD}$ (Spectro Analytical Instruments $\mathrm{GmbH}$ ). The solid samples were treated with a mixture of concentrated $\mathrm{HCl}: \mathrm{HNO}_{3}: \mathrm{HF}$ using microwave heating up to $220{ }^{\circ} \mathrm{C}$ for $40 \mathrm{~min}$ to dissolve all metal from the catalyst for the analysis (the mixture was prepared based on volumetric ratios; CAUTION: HF is extremely harmful, and relevant safety precautions must be taken). The instrument was calibrated for Pt $(214.423 \mathrm{~nm})$ and $\mathrm{Ga}(417.206 \mathrm{~nm})$ with standard solutions of the elements prior to the analysis.

$\mathrm{N}_{2}$-Sorption Measurements to Determine Surface Area and Pore Size. The surface area and average pore size of the supports were determined by isothermal lowtemperature $\mathrm{N}_{2}$-sorption analysis at $77 \mathrm{~K}$ using a QUADROSORB SI Surface Area and Pore Size analyzer from Quantachrome Instruments. The multipoint-BET (BrunauerEmmett-Teller) model was used to determine the specific surface area and the $\mathrm{BJH}$ method was used to determine the average pore size. All supports were pretreated at $250{ }^{\circ} \mathrm{C}$ for 12 $h$ under high vacuum prior to the measurements.

Temperature-Programmed Desorption (TPD) with $\mathrm{CO}_{2}$ and $\mathrm{NH}_{3} \cdot \mathrm{CO}_{2}$ and $\mathrm{NH}_{3}$-TPD were performed using a Thermo Scientific TPDRO 1100 instrument equipped with a TCD sensor. Approximately $300 \mathrm{mg}$ of material was weighed and dried at $500{ }^{\circ} \mathrm{C}$ under helium flow. The sample was cooled to $40{ }^{\circ} \mathrm{C}$ and loaded with $\mathrm{CO}_{2}\left(\right.$ or $\mathrm{NH}_{3}$ ) for a duration of 60 min and subsequently purged with helium for $15 \mathrm{~min}$. The TPD data were obtained in a temperature range of 40 to 650 ${ }^{\circ} \mathrm{C}$ with a heating rate of $10{ }^{\circ} \mathrm{C} \mathrm{min}^{-1}$.

Scanning Electron Microscopy with Energy-Dispersive X-ray Spectroscopy (SEM-EDX). The SEM-EDX measurements were performed on a ZEISS Cross Beam 540 Gemini II scanning electron microscope equipped with an EDX detector from Oxford Instruments Group. Silver paste (Acheson Silver DAG 1415) was used to enhance the electrical conductivity. Additionally, the samples were PVD carbon coated prior to the investigations. SEM images were obtained at $3 \mathrm{kV}$ and $2 \mathrm{nA}$. For BSD (Backscatter electron detector) images a voltage of $20 \mathrm{kV}$ and a current of $2 \mathrm{nA}$ was used. EDX analysis was performed at $20 \mathrm{kV}$ and $1.1 \mathrm{nA}$. The EDX results show the K $\alpha 1$ map for Ga and M $\alpha 1$ map for Pt.

Propane Dehydrogenation (PDH) in a Fixed Bed Tubular Reactor. The as-prepared catalysts were tested for their activity in the propane dehydrogenation reaction. A continuous flow laboratory setup was used for these tests (see Figure S1, Supporting Information). The catalyst (1.2 g) was placed into the fixed-bed reactor (quartz glass of length 650 $\mathrm{mm}$ and inner diameter of $10 \mathrm{~mm}$ ) that was positioned inside an electrically heated tubular split furnace (Carbolite). The reactor was heated to the set point of 500,550 , or $600{ }^{\circ} \mathrm{C}$ using a heating ramp of $10{ }^{\circ} \mathrm{C} \mathrm{min}^{-1}$. After a stabilization time of $15 \mathrm{~min}$, the reaction was started by supplying $8.9 \mathrm{~mL}_{\mathrm{N}}$ $\mathrm{min}^{-1}$ propane (99.95\% purity, Linde Gas) as feed gas diluted in $89 \mathrm{~mL}_{\mathrm{N}}$ min $^{-1}$ helium (99.996\% purity, Linde Gas). The gas hourly space velocity (GHSV) was set to $4900 \mathrm{~mL}_{\text {gas }} \mathrm{g}_{\mathrm{Cat} \cdot \text { bed }}{ }^{-1}$ $\mathrm{h}^{-1}$ resulting in a residence time $(\tau)$ of $0.7 \mathrm{~s}$ at standard conditions.

Online Analysis of Reaction Products. The product stream was analyzed by online gas chromatography (GC) using a Bruker 456 GC equipped with a GC-Gaspro column $(30 \mathrm{~m} \times 0.320 \mathrm{~mm})$ and a flame ionization detector (FID). Mole fractions of compound $i\left(x_{i}\right)$ were calculated from peak areas and calibration factors, which were determined for every substance. The conversion of propane $\left(X_{\text {propane }}\right)$, the productivity, and the selectivity to propene $\left(S_{\text {propene }}\right)$ were calculated as follows:

$$
\begin{aligned}
& X_{\text {propane }}=\frac{x_{\text {propane }, 0}-x_{\text {propane }}}{x_{\text {propane }, 0}} \cdot 100 \% \\
& S_{\text {propene }}=\frac{x_{\text {propene }}}{x_{\text {propane }, 0}-x_{\text {propane }}} \cdot 100 \% \\
& \text { productivity }=\frac{\dot{n}_{\text {propane }, 0} \cdot\left(X_{\text {propane }} / 100\right) \cdot\left(S_{\text {propene }} / 100\right) \cdot \mathrm{MW}_{\text {propene }}}{m_{\mathrm{Pt}}}
\end{aligned}
$$

where $x_{i}$ is the mole fraction and $x_{i, o}$ is the initial mole fraction of compound $i$ as calculated based on online-GC analysis, $\dot{n}_{\text {propane }, 0}$ is the total mole flow rate of propane in the feed, and MW $_{\text {propene }}$ is the molar weight of propene.

Postrun, High-Resolution Thermogravimetric Analysis Coupled with Mass Spectrometry (HRTGA-MS). Carbon deposits in the spent catalysts after PDH were characterized by means of high-resolution thermogravimetric analysis coupled with mass spectrometry (HRTGA-MS) using a XEMIS sorption analyzer (Hiden Isochema). ${ }^{25} \mathrm{~A}$ total of $\sim 200 \mathrm{mg}$ of the sample was placed in a cylindrical stainless steel mesh sample holder, heated to $120{ }^{\circ} \mathrm{C}\left(5{ }^{\circ} \mathrm{C} \mathrm{min}^{-1}\right)$ under an inert $\mathrm{He}$ atmosphere for $6 \mathrm{~h}$. Together with a subsequent heating to $500{ }^{\circ} \mathrm{C}\left(5{ }^{\circ} \mathrm{C} \mathrm{min}{ }^{-1}\right)$ for $12 \mathrm{~h}$, this procedure can be expected to remove adsorbed $\mathrm{H}_{2} \mathrm{O}$ from the sample under investigation. After the sample was cooled to 100 ${ }^{\circ} \mathrm{C}$ under a continuous $\mathrm{He}$ flow, $21 \% \mathrm{O}_{2} / \mathrm{He}$ was introduced for $1 \mathrm{~h}$ at $100{ }^{\circ} \mathrm{C}$. Subsequently, the temperature was increased with a heating rate of $1{ }^{\circ} \mathrm{C} \mathrm{min}^{-1}$ up to the maximum temperature of $500{ }^{\circ} \mathrm{C}$ for $12 \mathrm{~h}$. The overall flow rate was 100 $\mathrm{mL}_{\mathrm{N}} \min ^{-1}$ throughout TPO. A mass spectrometer (MS; Hiden Analytical) continuously analyzed the off-gas. The baselines of the MS signals were deducted in order to fit the 
Table 1. Characteristic Data for the Support Materials and the Catalyst Applied in This Study ${ }^{a}$

\begin{tabular}{|c|c|c|c|c|c|c|}
\hline system & $\begin{array}{l}\text { concentration of basic sites (support/catalyst) } \\
\qquad \mu \mathrm{mol} \mathrm{g}^{-1}\end{array}$ & $\begin{array}{l}\text { concentration of acidic sites (support/catalyst) } \\
\qquad \mu \mathrm{mol} \mathrm{g}^{-1}\end{array}$ & $\begin{array}{c}S_{\mathrm{BET}} \\
\mathrm{m}^{2} \mathrm{~g}^{-1}\end{array}$ & $\begin{array}{c}V_{\text {pore }} \\
\mathrm{mL} \mathrm{g}^{-1}\end{array}$ & $\begin{array}{c}d_{\text {pore }} \\
\mathrm{nm}\end{array}$ & $\begin{array}{c}D_{\text {particle }} \\
\mu \mathrm{m}\end{array}$ \\
\hline $\mathrm{Al}_{2} \mathrm{O}_{3}$ & $94 / 103$ & $480 / 507$ & 136 & 0.28 & 5 & $50-150$ \\
\hline $\mathrm{SiO}_{2}$ & $6 / 6$ & $21 / 80$ & 287 & 0.98 & 9 & $75-200$ \\
\hline $\mathrm{SiC}$ & $5 / 7$ & $7 / 75$ & 23 & 0.20 & 38 & $500-630$ \\
\hline
\end{tabular}

${ }^{a} S_{\mathrm{BET}}=$ specific surface area determined by BET method; $V_{\text {pore }}=$ specific pore volume determined by BJH method; $d_{\text {pore }}=$ average pore diameter determined by $\mathrm{BJH}$ method; $D_{\text {particle }}=$ particle size range determined by sieving.

peaks in MATLAB ${ }^{26}$ with the peakfit.m ${ }^{27}$ algorithm of the file exchange database. Lastly, the quantification of carbon deposits in the spent SCALMS was linked with the activity during PDH by calculating the selectivity toward coke $\left(S_{\text {coke }}\right)$ according to eq 4.

$$
S_{\text {coke }}=\frac{\frac{x_{\text {coke }} \cdot m_{\text {bed }}}{M_{\mathrm{C}}}}{\int 3 \cdot F_{\mathrm{C}_{3} \mathrm{H}_{8}}(t) \cdot X_{\mathrm{C}_{3} \mathrm{H}_{8}}(t) \mathrm{d} t} \cdot 100 \%
$$

where $x_{\text {coke }}$ is the fraction of coke as identified during HRTGAMS, $m_{\text {bed }}$ is the bed loading during PDH of $1.2 \mathrm{~g}, M_{\mathrm{C}}$ and $M_{\mathrm{C}_{3} \mathrm{H}_{8}}$ are the molecular weights of carbon and propane, respectively, $F_{\mathrm{C}_{3} \mathrm{H}_{8}}$ is the molar flow of propane in the feed, and $X_{\mathrm{C}_{3} \mathrm{H}_{8}}$ is the conversion of propane.

Postrun Raman Spectroscopy. Qualitative analysis of carbon deposits in spent SCALMS was also conducted via Raman spectroscopy using an AvaRaman-532HERO-EVO (Avantes) system with an AvaRaman-PRB-532 (Avantes) probe. The Raman setup consists of a $532 \mathrm{~nm}$ (green) solidstate laser (Cobolt) and an AvaSpec-HERO (Avantes) spectrometer with a grating set of 1200 lines $\mathrm{mm}^{-1}$ (HSC1200-0.75). The spectrometer was equipped with a 50 $\mu \mathrm{m}$ slit, and the detected wavelength range was 534-696 nm. The Raman spectra were collected in 20 repetitions at $15 \mathrm{~mW}$ laser power with an exposure time of $5 \mathrm{~s}$.

\section{RESULTS AND DISCUSSION}

Catalyst Characterization. Three supports, namely, alumina $\left(\mathrm{Al}_{2} \mathrm{O}_{3}\right)$, silica $\left(\mathrm{SiO}_{2}\right)$, and silicon carbide $(\mathrm{SiC})$, were used to prepare catalysts for propane dehydrogenation. The textural characteristics of the used support materials are shown in Table 1. All supports were characterized by $\mathrm{N}_{2}$ sorption (see Figure S2, Supporting Information). $\mathrm{SiO}_{2}$ and $\mathrm{Al}_{2} \mathrm{O}_{3}$ were used as provided by the supplier. $\mathrm{SiC}$ was purchased as $3 \mathrm{~mm}$-pellets and ground to a smaller size. The fraction of $500-630 \mu \mathrm{m}$ size was selected as the suitable particle size. The applied $\mathrm{SiO}_{2}$ and $\mathrm{Al}_{2} \mathrm{O}_{3}$ supports had an average pore size of less than $10 \mathrm{~nm}$. SiC had much larger pores in the range of $30-50 \mathrm{~nm}$. It must be noted here that although $\mathrm{SiO}_{2}$ and $\mathrm{Al}_{2} \mathrm{O}_{3}$ provide high surface area, the gallium is most likely deposited to a large extent on the external surface as most of the liquid metal droplets generated by ultrasonication typically exceed the average pore diameters. ${ }^{22}$ Our $\mathrm{CO}_{2}$-TPD of $\mathrm{Al}_{2} \mathrm{O}_{3}$ showed that the basic site concentration on $\mathrm{Al}_{2} \mathrm{O}_{3}$ was $94 \mu \mathrm{mol} \mathrm{g}{ }^{-1}$, which is significantly higher than that for the applied $\mathrm{SiO}_{2}$ and $\mathrm{SiC}\left(6\right.$ and $\left.5 \mu \mathrm{mol} \mathrm{g}^{-1}\right) . \mathrm{CO}_{2}-$ TPD of the synthesized catalyst indicates that the deposition of $\mathrm{Ga}$ and $\mathrm{Pt}$ only marginally changes the basic site concentration. The acidic site concentration from $\mathrm{NH}_{3}$-TPD on $\mathrm{Al}_{2} \mathrm{O}_{3}$ was found to be $480 \mu \mathrm{mol} \mathrm{g}^{-1}$ as opposed to 21 and $7 \mu \mathrm{mol} \mathrm{g}$ for $\mathrm{SiO}_{2}$ and $\mathrm{SiC}$, respectively. After synthesis, all catalysts showed a significant increase in the acid site concentration. This increase is largely due to indirect acid treatment that the material undergoes by the addition of hexachloroplatinic acid.

In addition to the SCALMS catalyst synthesized by ultrasonication, a SCALMS catalyst $\left(\mathrm{Ga}_{49} \mathrm{Pt}\right.$ on $\left.\mathrm{Al}_{2} \mathrm{O}_{3}\right)$ was also synthesized by the chemical route as described in an earlier publication. ${ }^{3}$ In order to discriminate the effect of each component in a SCALMS catalyst, Ga on a support and Pt on support materials were also synthesized on each of the three supports in addition to the SCALMS catalysts. The SCALMS catalysts were prepared with a targeted $\mathrm{Ga} / \mathrm{Pt}$ ratio $>40$ to ensure a fully liquid system under the applied reaction conditions. According to the GaPt phase diagram known from the literature, such a composition becomes fully liquid at approximately $300{ }^{\circ} \mathrm{C}$. The elemental composition of the different catalysts was determined by ICP-AES and is given in Table 2.

Table 2. Composition of All Catalysts Investigated in This Study as Determined by ICP-AES Measurements

\begin{tabular}{lccc}
\multicolumn{1}{c}{ system } & $\begin{array}{c}\mathrm{Ga} \\
\text { wt.- } \%\end{array}$ & $\begin{array}{c}\mathrm{Pt} \\
\text { wt.- } \%\end{array}$ & $\begin{array}{c}\mathrm{Ga}: \mathrm{Pt} \\
\text { mol }_{\mathrm{Ga}} \mathrm{mol}_{\mathrm{Pt}}{ }^{-1}\end{array}$ \\
$\mathrm{Ga} / \mathrm{Al}_{2} \mathrm{O}_{3}$ & 4.22 & - & - \\
$\mathrm{Pt} / \mathrm{Al}_{2} \mathrm{O}_{3}$ & - & 0.32 & - \\
$\mathrm{Ga}_{49} \mathrm{Pt}_{\mathrm{Al}} / \mathrm{Al}_{3}$ & 2.11 & 0.12 & 49 \\
$\mathrm{Ga} / \mathrm{SiO}_{2}$ & 4.50 & - & - \\
$\mathrm{Pt} / \mathrm{SiO}_{2}$ & - & 0.20 & - \\
$\mathrm{Ga}{ }_{48} \mathrm{Pt} / \mathrm{SiO}_{2}$ & 3.63 & 0.21 & 48 \\
$\mathrm{Ga} / \mathrm{SiC}$ & 4.28 & - & - \\
$\mathrm{Pt} / \mathrm{SiC}$ & - & 0.62 & - \\
$\mathrm{Ga}{ }_{41} \mathrm{Pt} / \mathrm{SiC}$ & 2.21 & 0.15 & 41 \\
$\mathrm{Ga}{ }_{49} \mathrm{Pt}-\mathrm{Chem} / \mathrm{Al}_{2} \mathrm{O}_{3}$ & 6.25 & 0.36 & 49 \\
\hline
\end{tabular}

Scanning electron microscopy was applied to characterize the morphology of all catalysts prepared (Figure 3). The images reveal differences induced by the applied support materials. The $\mathrm{Al}_{2} \mathrm{O}_{3}$ particles consist of clusters of crystallites of different orientation, resulting in a large number of corners and edges. The $\mathrm{SiO}_{2}$ particles are spherical on a macroscopic level. On the $\mathrm{SiC}$, no clear facets or flat surface areas can be identified. Even at high magnifications, $\mathrm{SiO}_{2}$ shows a smooth surface, while the surface of $\mathrm{Al}_{2} \mathrm{O}_{3}$ reveals unidirectional cracks of about $100 \mathrm{~nm}$ in width running across the flat surfaces. SiC has an uneven and rough surface. More interesting in the context of our study is the distribution of the metallic droplets over the external surface. The latter is inhomogeneous on all supports. While metallic droplets aggregate in the cracks of the $\mathrm{Al}_{2} \mathrm{O}_{3}$ support, no such defects are present on $\mathrm{SiO}_{2}$ resulting in a more uniform distribution over the surface. The uneven surface of $\mathrm{SiC}$ also promotes aggregation. In general, aggregation to larger droplets hints toward weak interaction between the alloy droplets and the support surface. Note that all Ga droplets have been initially generated by the same 

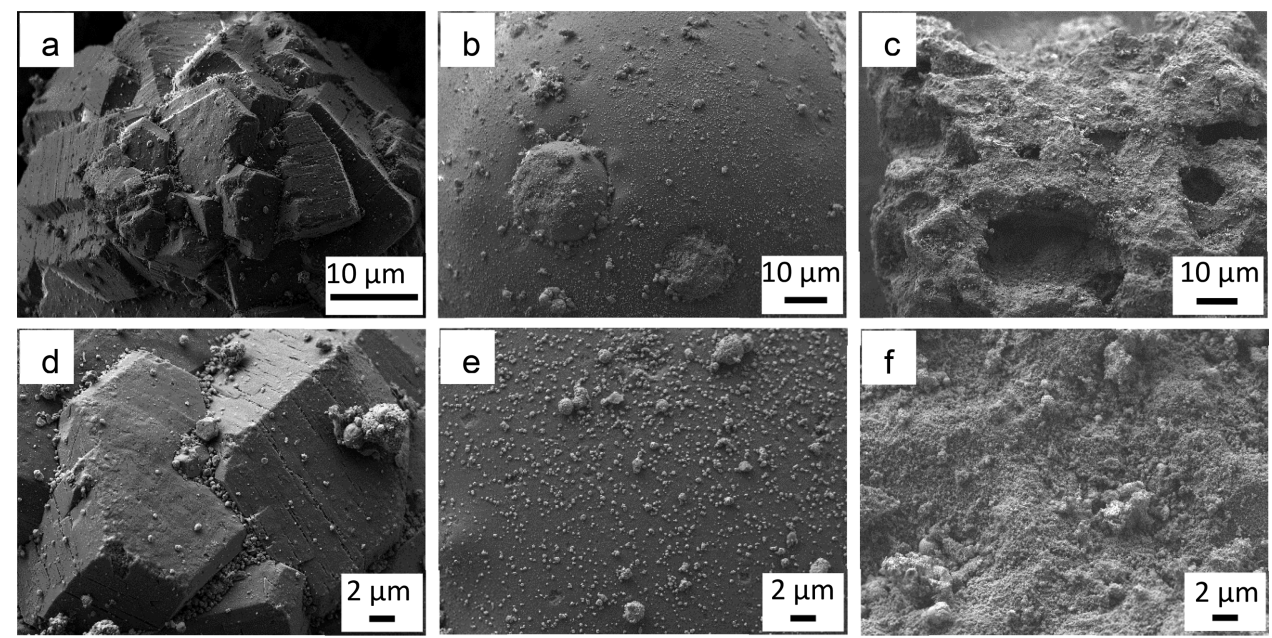

Figure 3. SEM images of as prepared GaPt-SCALMS catalyst supported on $\mathrm{Al}_{2} \mathrm{O}_{3}(\mathrm{a}, \mathrm{d}), \mathrm{SiO}_{2}(\mathrm{~b}, \mathrm{e})$ and $\mathrm{SiC}(\mathrm{c}, \mathrm{f})$ at low magnification (top row), higher magnification (bottom row).
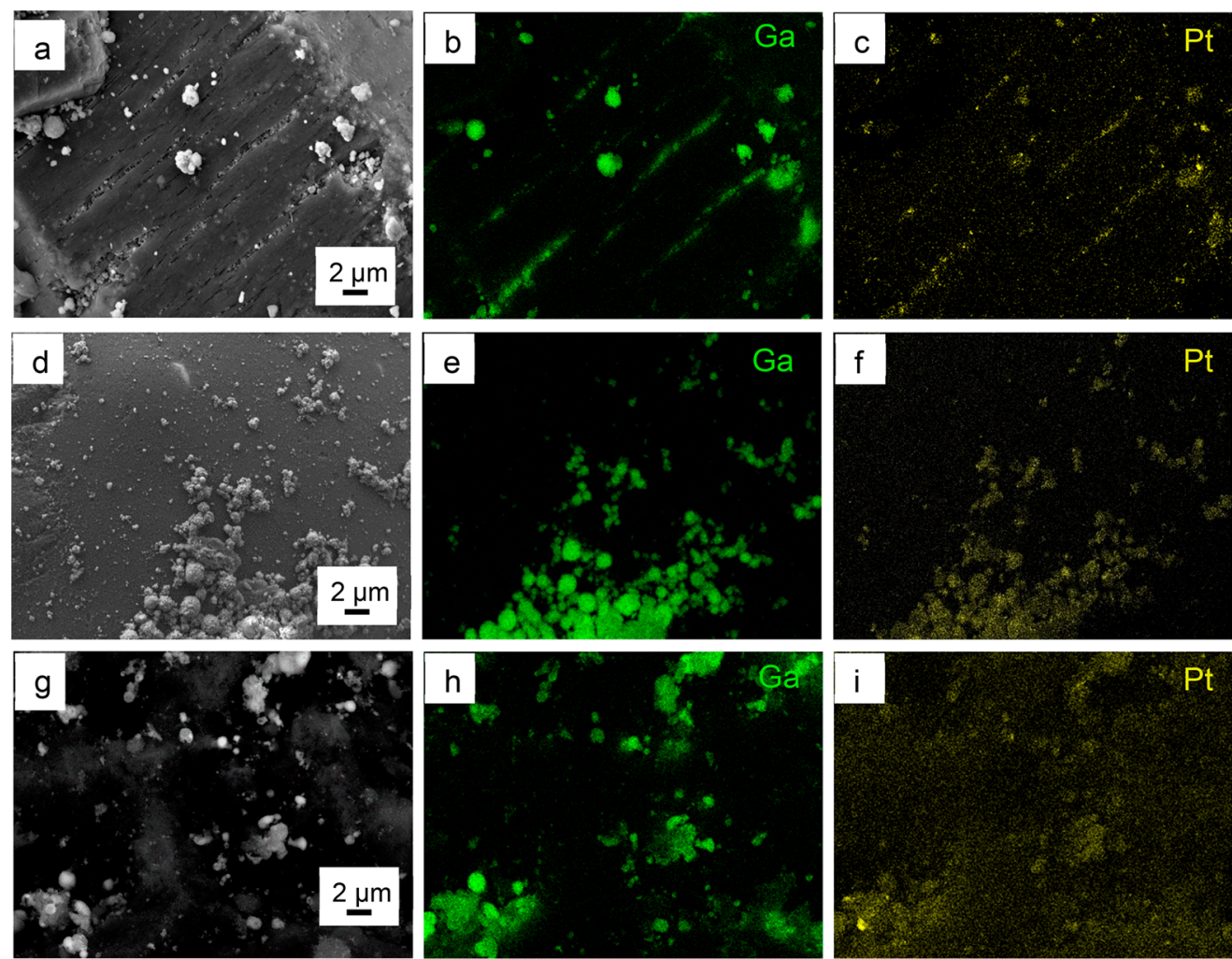

Figure 4. SEM-EDX images showing the distribution of gallium $(\mathrm{Ga})$ and platinum $(\mathrm{Pt})$ on $\mathrm{Ga}-\mathrm{Pt} \mathrm{SCALMS}$ catalyst supported on $\mathrm{Al}_{2} \mathrm{O}_{3}(\mathrm{a}-\mathrm{c})$, $\mathrm{SiO}_{2}(\mathrm{~d}-\mathrm{f}), \mathrm{SiC}(\mathrm{g}-\mathrm{i})$.

ultrasonication method in isopropanol under identical conditions prior to addition of the support material.

The distribution of gallium and platinum was further analyzed by SEM-EDX (Figure 4). As platinum is introduced to the materials by galvanic displacement, most of it is expected to be found at the gallium droplets. EDX mapping of the metals for the freshly prepared catalysts (Figure 4) as well as for the spent catalyst (see Figure S8, Supporting Information) shows indeed this colocation of $\mathrm{Ga}$ and $\mathrm{Pt}$ on the surface of the alloy droplets or crystallites for all materials.

Catalytic Results in Propane Dehydrogenation (PDH). In order to determine potential effects of the new SCALMS preparation route on the catalytic performance, we first compared the performance of $\mathrm{Ga}_{49} \mathrm{Pt}$-SCALMS on $\mathrm{Al}_{2} \mathrm{O}_{3}$ prepared by the traditional chemical route with the same composition prepared by our new ultrasonification method. Catalytic productivity and selectivity in propane dehydrogenation at $550{ }^{\circ} \mathrm{C}$ were evaluated (Figure 5, left). Interestingly, the catalyst prepared by ultrasonication showed an initial productivity close to $65 \mathrm{~g}_{\text {propene }} \mathrm{g}_{\mathrm{Pt}}{ }^{-1} \mathrm{~h}^{-1}$ compared with 50 g propene $\mathrm{g}_{\mathrm{Pt}}^{-1} \mathrm{~h}^{-1}$ for the catalyst prepared by the chemical route. The propene selectivity was also slightly higher for the catalyst prepared by ultrasonication (Figure 5, right). In particular, the catalyst produced by the chemical route showed 

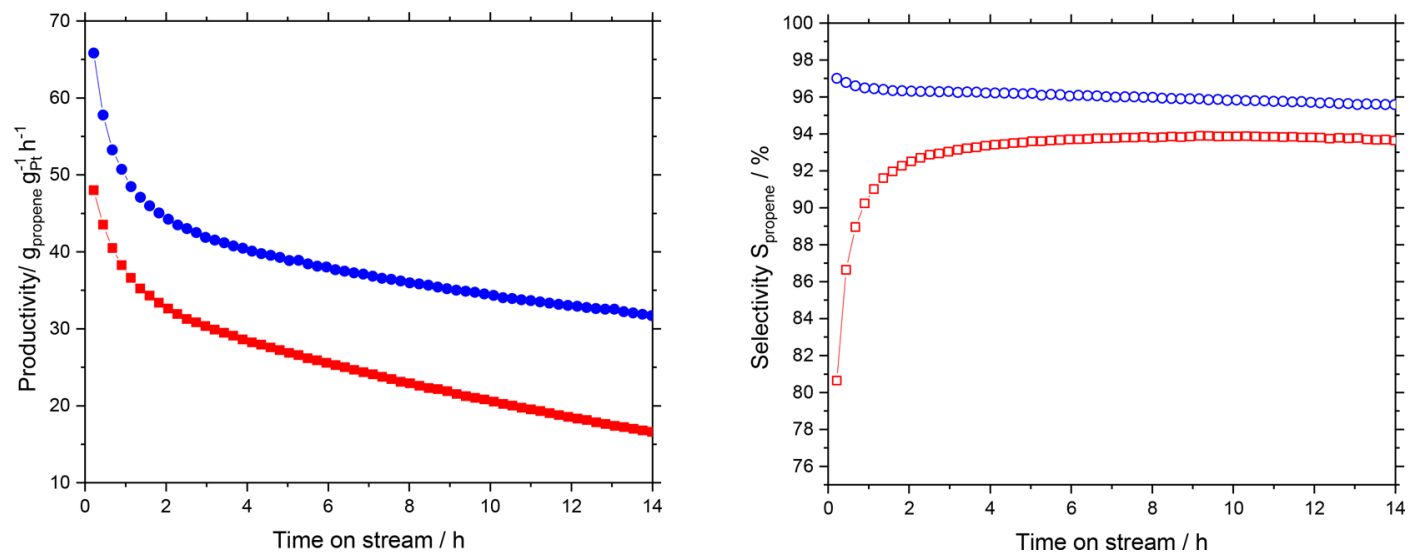

Figure 5. Productivity (filled symbols) and selectivity (open symbols) in propane dehydrogenation using different GaPt-SCALMS supported on $\mathrm{Al}_{2} \mathrm{O}_{3}$ prepared by ultrasonication (blue symbols), and the chemical route (red symbols) at $550{ }^{\circ} \mathrm{C}$ and 1.2 bar. Reaction conditions: $1.2 \mathrm{~g}$ catalyst $\left(\mathrm{Ga}_{49} \mathrm{Pt} / \mathrm{Al}_{2} \mathrm{O}_{3}: 2.11 \mathrm{wt}-\% \mathrm{Ga}, 0.12 \mathrm{wt}-\% \mathrm{Pt} ; \mathrm{Ga}_{49} \mathrm{Pt}-\mathrm{Chem} / \mathrm{Al}_{2} \mathrm{O}_{3} 6.25 \mathrm{wt}-\% \mathrm{Ga}, 0.36 \mathrm{wt}-\% \mathrm{Pt}\right)$ He flow $89 \mathrm{~mL}_{\mathrm{N}} \mathrm{min}^{-1}, \mathrm{C}_{3} \mathrm{H}_{8}$ flow $8.9 \mathrm{~mL}_{\mathrm{N}} \mathrm{min}^{-1}$, GHSV $4900 \mathrm{~mL}_{\text {gas }} \mathrm{g}_{\text {Cat bed }}{ }^{-1} \mathrm{~h}^{-1}$.

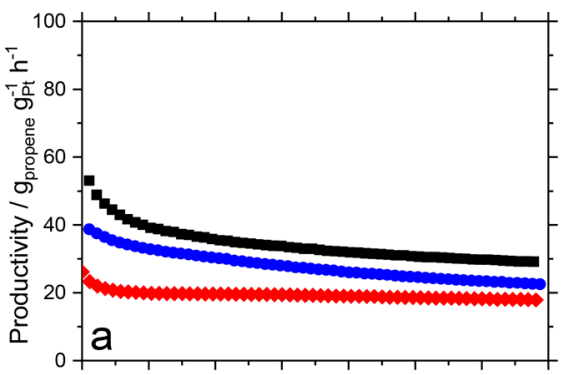

$500^{\circ} \mathrm{C}$

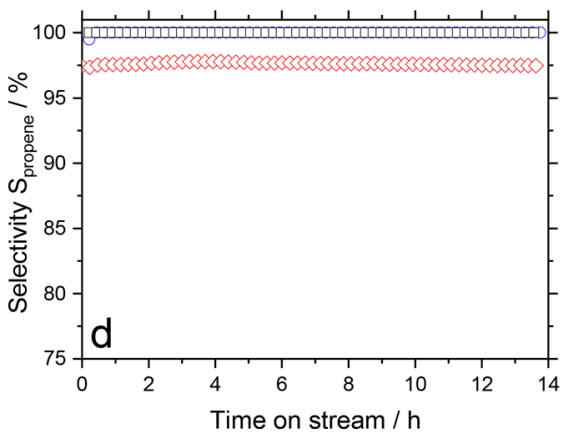

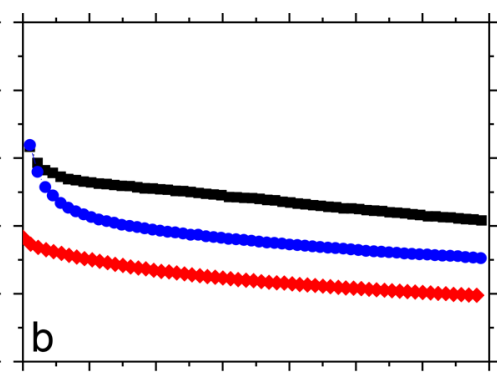

$550^{\circ} \mathrm{C}$

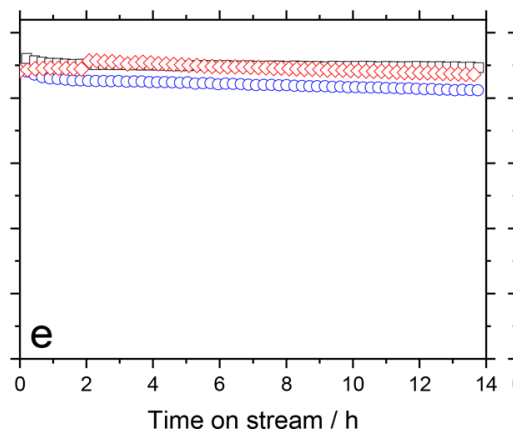

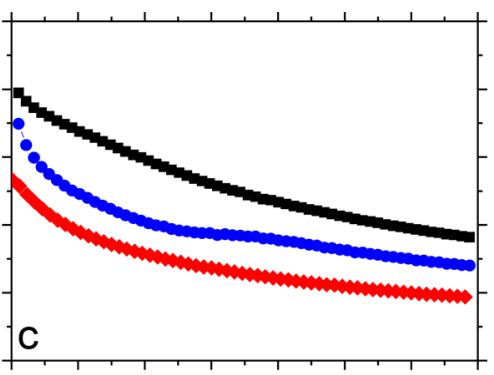

$600^{\circ} \mathrm{C}$

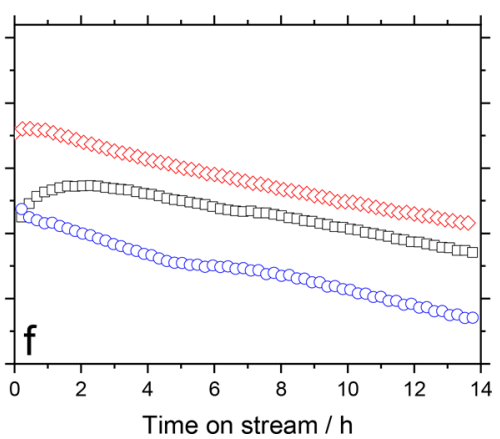

Figure 6. Productivity (filled symbols, a-c) and selectivity (open symbols, $\mathrm{d}-\mathrm{f}$ ) in propane dehydrogenation using different GaPt-SCALMS supported on $\mathrm{Al}_{2} \mathrm{O}_{3}$ (blue symbols), $\mathrm{SiO}_{2}$ (red symbols), and $\mathrm{SiC}$ (black symbols) at $500{ }^{\circ} \mathrm{C}(\mathrm{a}, \mathrm{d}), 550{ }^{\circ} \mathrm{C}(\mathrm{b}, \mathrm{e})$, and $600{ }^{\circ} \mathrm{C}(\mathrm{c}, \mathrm{f})$ at 1.2 bar. Reaction conditions: $1.2 \mathrm{~g}$ catalyst $\left(\mathrm{Ga}_{49} \mathrm{Pt} / \mathrm{Al}_{2} \mathrm{O}_{3}: 2.11\right.$ wt- $\% \mathrm{Ga}, 0.12$ wt- $\% \mathrm{Pt} ; \mathrm{Ga}_{48} \mathrm{Pt} / \mathrm{SiO}_{2}: 3.63$ wt- $\% \mathrm{Ga}, 0.21 \mathrm{wt}-\% \mathrm{Pt} ; \mathrm{Ga}{ }_{41} \mathrm{Pt} / \mathrm{SiC}: 2.2 \mathrm{wt}-\%$ Ga, $0.15 \mathrm{wt}$ \% Pt) He flow $89 \mathrm{~mL}_{\mathrm{N}} \mathrm{min}^{-1}, \mathrm{C}_{3} \mathrm{H}_{8}$ flow $8.9 \mathrm{~mL}_{\mathrm{N}} \mathrm{min}^{-1}$, GHSV $4900 \mathrm{~mL}_{\text {gas }} \mathrm{g}_{\text {Cat.bed }}{ }^{-1} \mathrm{~h}^{-1}$.

a higher tendency toward cracking in the beginning. Overall, these results show that the preparation method based on Ga ultrasonication is a surprisingly attractive alternative to the somewhat tedious chemical preparation route to SCALMS materials. Note that the synthesis of the $\mathrm{Ga}$ precursor $\left(\mathrm{Et}_{3} \mathrm{~N}\right) \mathrm{GaH}_{3}$ needed for the chemical route requires protective dry/inert conditions and the use of a large excess of $\mathrm{LiH}$, which affords very careful handling and produces significant amounts of noxious waste. ${ }^{28}$ The production of SCALMS materials by ultrasonication, in contrast, is carried out in an alcoholic solvent without even the need for a protective atmosphere. This preparation route starts from elemental $\mathrm{Ga}$ and is characterized by almost perfect atom efficiency.

With the convenient and scalable SCALMS preparation via ultrasonication at hand, we proceeded with our further investigations of support effects on the catalytic performance in propane dehydrogenation at temperatures of 500,550, and $600{ }^{\circ} \mathrm{C}$ (Figure 6). Reference experiments with $\mathrm{Ga} /$ support and $\mathrm{Pt}$ /support catalysts under similar conditions were also conducted for comparison (see Supporting Information, Figures S12-17). At $500{ }^{\circ} \mathrm{C}$ (Figure 6a,d), $\mathrm{Ga}_{41} \mathrm{Pt} / \mathrm{SiC}$ showed the highest productivity of $53 \mathrm{~g}_{\text {propene }} \mathrm{g}_{\mathrm{Pt}} \mathrm{h}^{-1}$, while the $\mathrm{Ga}_{49} \mathrm{Pt} / \mathrm{Al}_{2} \mathrm{O}_{3}$ and $\mathrm{Ga}_{48} \mathrm{Pt} / \mathrm{SiO}_{2}$ SCALMS catalysts showed a productivity of 40 and $25 \mathrm{~g}_{\text {propene }} \mathrm{g}_{\mathrm{Pt}} \mathrm{h}^{-1}$, respectively. At this temperature, all catalysts showed a propene selectivity exceeding 95\%. The $\mathrm{SiO}_{2}$-based catalyst, however, showed a very stable activity for $14 \mathrm{~h}$ after a slight initial deactivation. At $550{ }^{\circ} \mathrm{C}, \mathrm{Al}_{2} \mathrm{O}_{3}$ and $\mathrm{SiC}$-based catalysts showed a very similar initial productivity of about $65 \mathrm{~g}_{\text {propene }} \mathrm{g}_{\mathrm{Pt}} \mathrm{h}^{-1}$, while $\mathrm{SiO}_{2}$-based catalyst had an initial productivity of $40 \mathrm{~g}_{\text {propene }} \mathrm{g}_{\mathrm{Pt}} \mathrm{h}^{-1}$. In all 

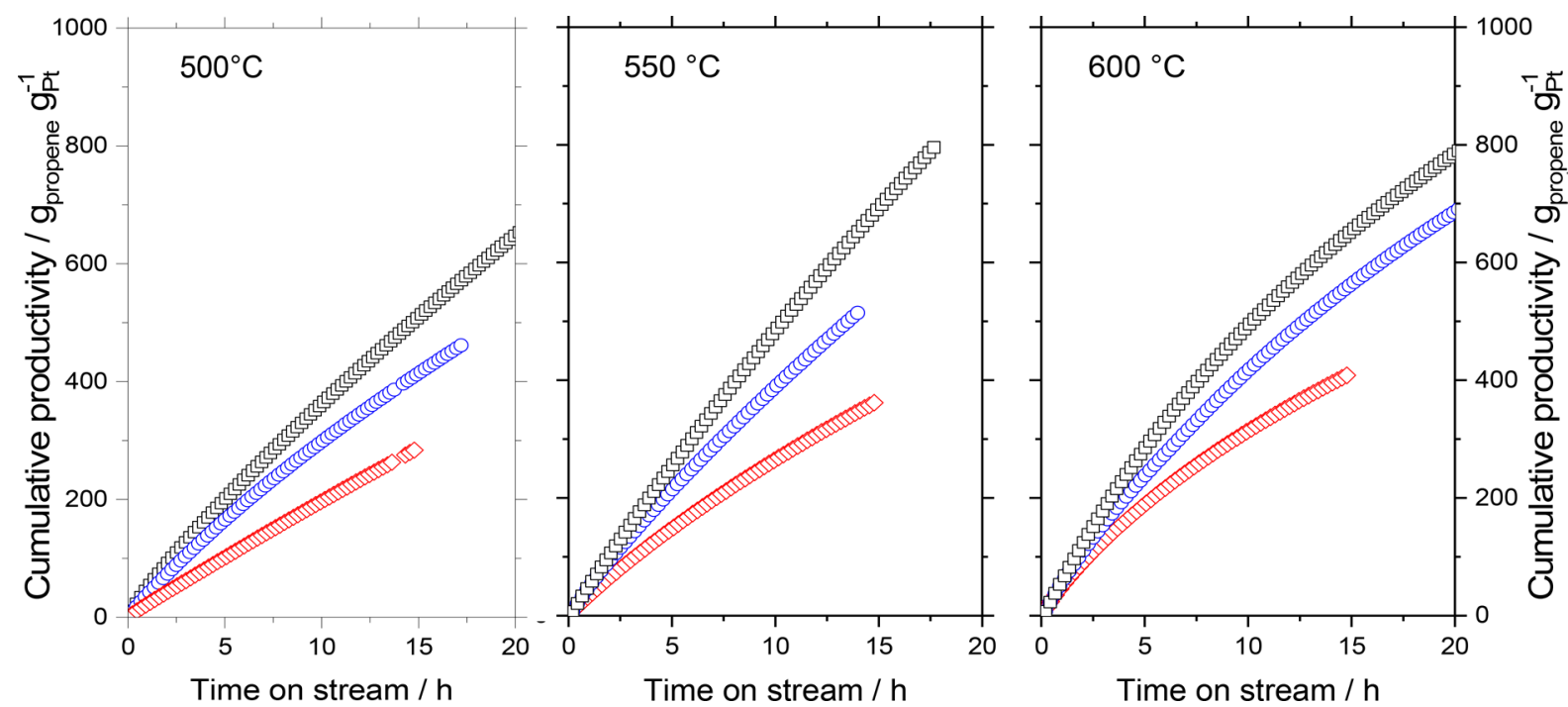

Figure 7. Cumulative productivity in propane dehydrogenation using different $\mathrm{GaPt}$ SCALMS supported on $\mathrm{Al}_{2} \mathrm{O}_{3}$ (blue symbols), $\mathrm{SiO}_{2}$ (red symbols), and $\mathrm{SiC}$ (black symbols) at $500{ }^{\circ} \mathrm{C}$ (left), $550{ }^{\circ} \mathrm{C}$ (center), and $600{ }^{\circ} \mathrm{C}$ (right) and 1.2 bar. Reaction conditions: $1.2 \mathrm{~g}$ catalyst $\left(\mathrm{Ga}{ }_{49} \mathrm{Pt} /\right.$ $\mathrm{Al}_{2} \mathrm{O}_{3}: 2.11$ wt-\% Ga, 0.12 wt-\% Pt; $\mathrm{Ga}_{48} \mathrm{Pt} / \mathrm{SiO}_{2}$ : 3.63 wt-\% Ga, 0.21 wt-\% Pt; $\left.\mathrm{Ga}_{41} \mathrm{Pt} / \mathrm{SiC}: 2.2 \mathrm{wt}-\% \mathrm{Ga}, 0.15 \mathrm{wt}-\% \mathrm{Pt}\right) \mathrm{He}$ flow $89 \mathrm{~mL}$ min ${ }^{-1}$, $\mathrm{C}_{3} \mathrm{H}_{8}$ flow $8.9 \mathrm{~mL}_{\mathrm{N}} \mathrm{min}^{-1}$, GHSV $4900 \mathrm{~mL}_{\text {gas }} \mathrm{g}_{\text {Cat bed }}{ }^{-1} \mathrm{~h}^{-1}$.

cases, a certain deactivation over $14 \mathrm{~h}$ time on stream was observed, but $\mathrm{SiO}_{2}$ and $\mathrm{SiC}$-based catalyst showed a more stable performance compared with the $\mathrm{Al}_{2} \mathrm{O}_{3}$-based catalyst. The activity levels remained in all cases above $50 \%$ of the initial activity. The propene selectivity was stable at values above $95 \%$ for all three catalysts under investigation (Figure 6b,e). At 600 ${ }^{\circ} \mathrm{C}$, the $\mathrm{Al}_{2} \mathrm{O}_{3}$ and $\mathrm{SiC}$ showed initial productivity in the range of 70 to $80 \mathrm{~g}_{\text {propene }} \mathrm{g}_{\mathrm{Pt}} \mathrm{h}^{-1}$, while $\mathrm{SiO}_{2}$ was the least active with an initial productivity just over $50 \mathrm{~g}_{\text {propene }} \mathrm{g}_{\mathrm{Pt}} \mathrm{h}^{-1}$. Loss in productivity of all three catalysts after $14 \mathrm{~h}$ time on stream was significantly higher than at $550{ }^{\circ} \mathrm{C}$ after the same time on stream. Remarkably, the propene selectivity was significantly lower than at $550{ }^{\circ} \mathrm{C}$ despite the very similar level of conversion, at least after $14 \mathrm{~h}$ time-on-stream. Moreover, the selectivity for SCALMS materials on all three supports showed a steady decline in contrast to the same materials at $550{ }^{\circ} \mathrm{C}$ (Figure 6c,f). It is an interesting observation that the formation of cracked products remained almost constant over time for all three materials tested at $600{ }^{\circ} \mathrm{C}$. Thus, the declining selectivity trend is a consequence of a stable side product formation against a steadily reducing propene formation. This clearly indicates that most of the cracking takes place independent from the catalytic site responsible for the dehydrogenation reaction, probably directly at the support material. All catalysts showed some degree of deactivation at all temperatures. A closer analysis (see Supporting Information, Figures S2-4, for details) reveals two deactivation regimes at play. At $500{ }^{\circ} \mathrm{C}$, the $\mathrm{SiO}_{2}$-supported catalyst showed a fast initial loss of activity, followed by a rather stable performance, while both $\mathrm{Al}_{2} \mathrm{O}_{3}$ - and $\mathrm{SiC}$-based materials showed an exponential decay in activity (see Figures S3-S5 in Supporting Information). At higher temperature, all catalysts irrespective of their support showed a deactivation behavior that is best fitted by a second-order decay function (see Table S1 in Supporting Information). We assume coking on the bare support surface to be one major reason for the observed deactivation. This coke (see TPO studies below) fouls the catalyst surface, reduces thereby the accessibility of active sites and consequently lowers the activity.
Noteworthy, the specific surface area $\left(S_{\mathrm{BET}}\right)$ of the support material does not seem to play a major role for the performance of the catalyst as $\mathrm{SiC}$, the support with the lowest $S_{\mathrm{BET}}$, is the most active catalyst. This is a consequence of the fact that $\mathrm{Ga}$ emulsification produces a majority of droplets that are bigger than the substrate pores ${ }^{20}$ (see Supporting Information, Particle Size Distribution). Therefore, a significant part of the Ga droplets will remain on the external surface of the support, where they still contribute to the overall catalytic activity.

From the selectivity and conversion values, the cumulative productivity ( $\mathrm{g}_{\text {propene }} \mathrm{g}_{\mathrm{Pt}}{ }^{-1}$ ) was calculated (see Figures 7 and S6-7 in the Supporting Information). Because of their high selectivity at $500{ }^{\circ} \mathrm{C}, \mathrm{Ga}_{49} \mathrm{Pt} / \mathrm{Al}_{2} \mathrm{O}_{3}$ and $\mathrm{Ga}_{41} \mathrm{Pt} / \mathrm{SiC}$ outperform the $\mathrm{SiO}_{2}$-based catalyst after $15 \mathrm{~h}$ with cumulative productivities of $410\left(\mathrm{Al}_{2} \mathrm{O}_{3}\right)$ and $510(\mathrm{SiC})$, whereas $\mathrm{Ga}_{48} \mathrm{Pt}$ / $\mathrm{SiO}_{2}$ only yields $290 \mathrm{~g}_{\text {propene }} \mathrm{g}_{\mathrm{Pt}}{ }^{-1} \cdot \mathrm{Ga}_{41} \mathrm{Pt} / \mathrm{SiC}$ as the most productive system was operated slightly longer and reached a cumulative productivity of $710 \mathrm{~g}_{\text {propene }} \mathrm{g}_{\mathrm{Pt}}{ }^{-1}$ after $22 \mathrm{~h}$, indicating good long-term performance. At 550 and $600{ }^{\circ} \mathrm{C}$, higher initial productivities were obtained for all systems at still reasonable selectivities and stabilities. The stronger deactivation at $600{ }^{\circ} \mathrm{C}$ offsets the gain in initial activity at higher temperature. As a result, the cumulative productivity values at $600{ }^{\circ} \mathrm{C}$ are nearly the same compared with those obtained at $550{ }^{\circ} \mathrm{C}$. At all temperatures under investigation, the SCALMS on $\mathrm{SiC}$ outperformed the two other support materials. The highest cumulative productivity was calculated for the $\mathrm{SiC}$ supported SCALMS system with a value of $800 \mathrm{~g}_{\text {propene }} \mathrm{g}_{\mathrm{Pt}}{ }^{-1}$ at $550{ }^{\circ} \mathrm{C}$ after only $18 \mathrm{~h}$ time-on-stream.

Table 3 summarizes the performance data for all catalysts under investigation for the three different temperatures.

Also the data in Table 3 indicate that among the tested materials and conditions the SiC-supported SCALMS catalyst at $550{ }^{\circ} \mathrm{C}$ is the best choice. $\mathrm{SiC}$ as support combines a low level of side product formation with good activity. At $500{ }^{\circ} \mathrm{C}$, selectivity is excellent and stable, but reactivity is significantly lower. At $600{ }^{\circ} \mathrm{C}$, a high initial activity is paired with 
Table 3. Propane Dehydrogenation Performance Data for the Different GaPt-SCALMS Catalysts Supported on $\mathrm{Al}_{2} \mathrm{O}_{3}$, $\mathrm{SiO}_{2}$, and $\mathrm{SiC}$ at Temperatures between 500 and $600{ }^{\circ} \mathrm{C}^{a}$

\begin{tabular}{cccccc}
$T$ & & $X_{0}$ & $S_{0}$ & $S_{14 h}$ & $\mathrm{CP}_{14 h}$ \\
${ }^{\circ} \mathrm{C}$ & catalyst & $\%$ & $\%$ & $\%$ & $\mathrm{~g}_{\text {propene }} \mathrm{g}_{\mathrm{Pt}}{ }^{-1}$ \\
\hline 500 & $\mathrm{Ga}_{48} \mathrm{Pt} / \mathrm{SiO}_{2}$ & 7.8 & 97.5 & 97.6 & 270 \\
& $\mathrm{Ga}_{49} \mathrm{Pt} / \mathrm{Al}_{2} \mathrm{O}_{3}$ & 6.4 & 99.5 & 99.9 & 390 \\
& $\mathrm{Ga}_{41} \mathrm{Pt} / \mathrm{SiC}^{5}$ & 11.5 & 99.9 & 99.9 & 480 \\
& $\mathrm{Ga}_{48} \mathrm{Pt} / \mathrm{SiO}_{2}$ & 11.4 & 97.1 & 96.7 & 350 \\
& $\mathrm{Ga}_{49} \mathrm{Pt} / \mathrm{Al}_{2} \mathrm{O}_{3}$ & 11.4 & 97.0 & 95.5 & 520 \\
& $\mathrm{Ga}_{41} \mathrm{Pt} / \mathrm{SiC}_{600}$ & 14.1 & 98.0 & 97.3 & 650 \\
& $\mathrm{Ga}_{48} \mathrm{Pt} / \mathrm{SiO}_{2}$ & 19.2 & 92.7 & 85.5 & 400 \\
& $\mathrm{Ga}_{49} \mathrm{Pt} / \mathrm{Al}_{2} \mathrm{O}_{3}$ & 14.4 & 86.9 & 78.4 & 540 \\
& $\mathrm{Ga}_{41} \mathrm{Pt} / \mathrm{SiC}$ & 18.5 & 86.2 & 83.4 & 630
\end{tabular}

${ }^{a} T=$ reactor temperature; $\mathrm{X}_{0}=$ initial conversion; $\mathrm{S}_{0}=$ initial propene selectivity; $\mathrm{S}_{14 \mathrm{~h}}=$ propene selectivity after $14 \mathrm{~h} ; \mathrm{CP}_{14 \mathrm{~h}}=$ cumulative productivity after $14 \mathrm{~h}$; CP data were smoothed to full digits.

significantly lower and falling selectivity combined with significant deactivation over time.

In the following, we aimed at elucidating the reasons for the different levels of deactivation observed for all SCALMS systems under investigation at the various process conditions. Two major reasons were considered: (i) coking of either active site or of the support limiting the access to the active site; (ii) coalescence of the liquid droplets in the SCALMS systems (especially for the part supported on the outer surface of the catalyst material). In order to gain the targeted insight into the relevant deactivation mechanisms at work, the spent catalyst was analyzed by TPO with HRTGA-MS for coke content determination and by SEM for morphological changes.
Postrun, High-Resolution Thermogravimetric Analysis Coupled with Mass Spectrometry (HRTGA-MS). The weight loss of a predried SCALMS sample in a TPO experiment in $21 \% \mathrm{O}_{2} / \mathrm{He}$ at $500{ }^{\circ} \mathrm{C}$ for $12 \mathrm{~h}$ can be considered to correspond to the amount of coke present in the sample. This method was applied to determine the coke content and the $\mathrm{CO}_{2}$ formation during TPO (as detected using the MS signal for a mass-to-charge ratio of 44) for all SCALMS samples after the respective catalytic runs. As seen from Figure 8 (see Supporting Information, Figure S9 for integral information on the $\mathrm{CO}_{2}$ signal), coke formation increases with temperature and support-wise in the order $\mathrm{SiO}_{2}<\mathrm{SiC}<$ $\mathrm{Al}_{2} \mathrm{O}_{3}$. This result is not unexpected, as the acidic sites on alumina enhance coke formation. In-line with its excellent stability, hardly any coke was detected on $\mathrm{GaPt} / \mathrm{SiO}_{2}$ after $\mathrm{PDH}$ at $500{ }^{\circ} \mathrm{C}$ for $14 \mathrm{~h}$ (see Figure 6). Additionally, at 600 ${ }^{\circ} \mathrm{C}$, only minor amounts of coke were detected (up to $0.12 \mathrm{wt}$.$\%$ after $14 \mathrm{~h} \mathrm{PDH}$ operation) on this support despite the observed significant deactivation. This observation is well inline with recent reports by some of us highlighting the high resistance of $\mathrm{GaPt} / \mathrm{SiO}_{2}$ SCALMS against coking, in contrast to $\mathrm{Al}_{2} \mathrm{O}_{3}$-supported SCALMS systems. ${ }^{29}$

The GaPt-SCALMS system on $\mathrm{SiC}$ showed after PDH at $600{ }^{\circ} \mathrm{C}$ a certain content of coke (net decrease of sample weight of 0.54 wt.- $\%$ in TPO), while after $\mathrm{PDH}$ at $550{ }^{\circ} \mathrm{C}$ coke formation was minimal, well in-line with the catalytic results.

The SCALMS system on alumina shows after use in PDH at $600{ }^{\circ} \mathrm{C}$ in the subsequent TPO experiment a marked weight increase during the heating process (mainly in the temperature range of $250-350{ }^{\circ} \mathrm{C}$, see Figure 8 ). Obviously, other processes affect the sample weight during TPO of spent SCALMS next to the oxidation of coke. Oxidation of gallium and/or the active metal are obvious options. Furthermore,
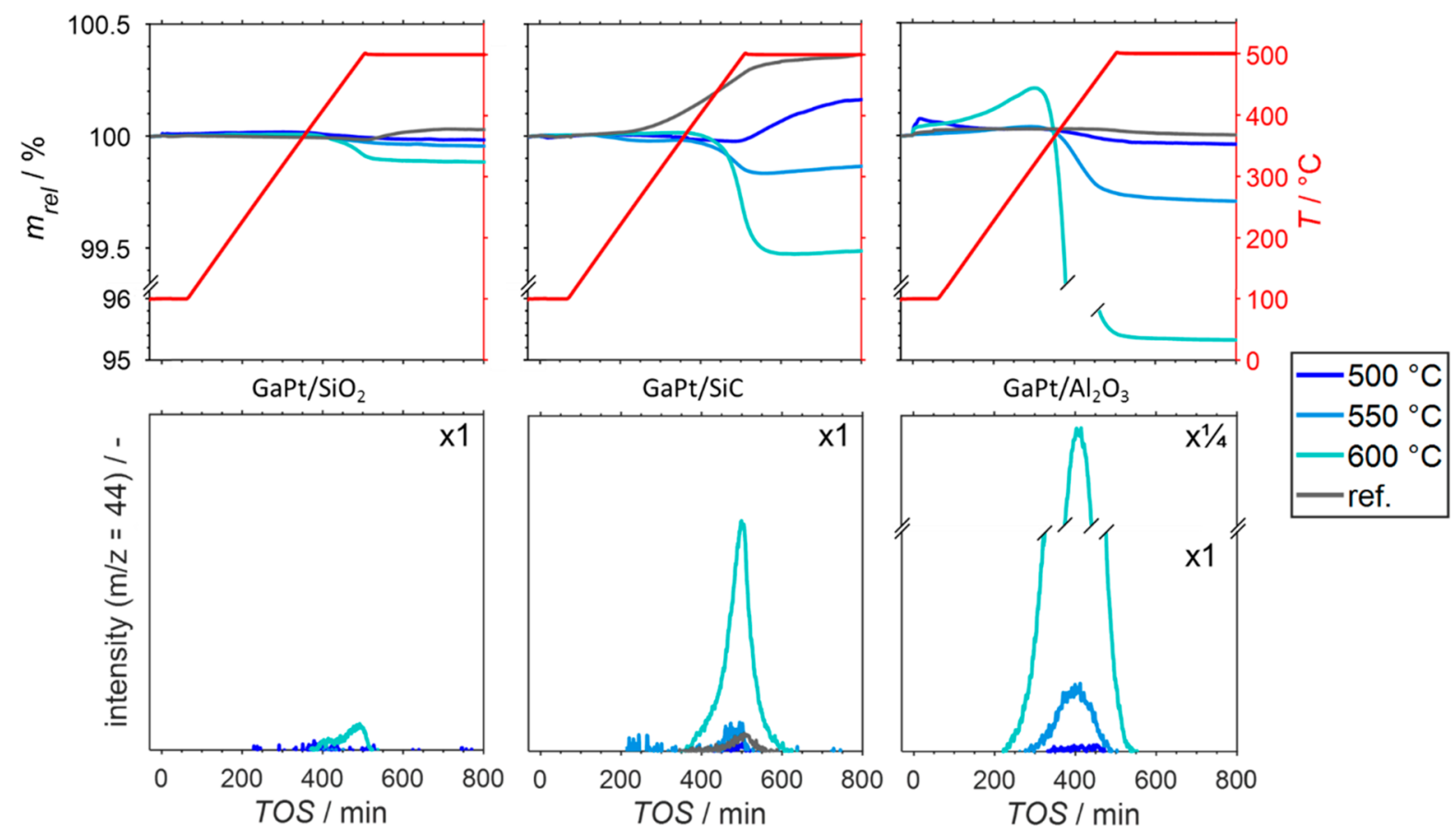

Figure 8. Sample weight relative to the weight prior to exposure to $21 \% \mathrm{O}_{2} / \mathrm{He}$ at $100{ }^{\circ} \mathrm{C}$ (top) and formation of $\mathrm{CO}_{2}$ (bottom) during temperature programmed oxidation $\left(1{ }^{\circ} \mathrm{C} \mathrm{min}{ }^{-1}\right.$ ) of spent $\mathrm{Ga}_{49} \mathrm{Pt} / \mathrm{Al}_{2} \mathrm{O}_{3}$ (left), $\mathrm{Ga}_{48} \mathrm{Pt} / \mathrm{SiO}_{2}$ (middle), and $\mathrm{Ga}_{41} \mathrm{Pt} / \mathrm{SiC}$ (right). These SCALMS systems were investigated after propane dehydrogenation at $500{ }^{\circ} \mathrm{C}$ (dark blue), $550{ }^{\circ} \mathrm{C}$ (blue), and $600{ }^{\circ} \mathrm{C}$ (light blue) together with the bare support materials (gray) by HRTG-MS. Conditions: $100 \mathrm{~mL}_{\mathrm{N}} \mathrm{min}^{-1} \mathrm{He}(\mathrm{TOS}<0)$; $79 \mathrm{~mL}_{\mathrm{N}} \mathrm{min}^{-1} \mathrm{He}$ and21 $\mathrm{mL}_{\mathrm{N}} \mathrm{min}^{-1} \mathrm{O}_{2}(\mathrm{TOS}>0)$; WHSV $30000 \mathrm{~mL}_{\mathrm{N}} \mathrm{g}^{-1} \mathrm{~h}^{-1}$. 
formation of oxygen-containing functionalities on carbon ${ }^{15}$ may also increase the sample weight during the temperature ramp to $500{ }^{\circ} \mathrm{C}$. Such a formation of carbon functionalities upon first exposure to $\mathrm{O}_{2}$ was previously identified during $\mathrm{TPO}$ of $\mathrm{GaRh} / \mathrm{Al}_{2} \mathrm{O}_{3}, \mathrm{GaPt} / \mathrm{Al}_{2} \mathrm{O}_{3}$, and $\mathrm{GaPt} / \mathrm{SiO}_{2}$ SCALMS. ${ }^{29,30}$ Also, potential effects of the support material on the sample weight have to be taken into account. Herein, only the bare $\mathrm{SiC}$ support resulted in a significant weight increase during TPO (Figure 8), most likely due to an extended surface passivation of the support material by $\mathrm{O}_{2}$ forming $\mathrm{SiO}_{2}$ and $\mathrm{CO}_{2}$. The formation of the latter is also evidenced via MS. This strong effect of the support material results in an underestimation of the amount of coke formed when considering the net weight change only.

We previously hypothesized that coke formation over the $\mathrm{Al}_{2} \mathrm{O}_{3}$ support material is enhanced during $\mathrm{PDH}$ at $550{ }^{\circ} \mathrm{C}$ compared with lower operation temperatures, that is, carbon deposition during $\mathrm{PDH}$ at elevated temperatures may be mostly caused by $\mathrm{Al}_{2} \mathrm{O}_{3}$ itself. $^{30}$ Further, coking on $\mathrm{Al}_{2} \mathrm{O}_{3}$ resulted in a highly reactive coke species, which could be oxidized at low temperatures as a result of highly reactive amorphous coke. The pronounced weight loss of $4.68 \mathrm{wt} .-\%$ of the $\mathrm{GaPt} / \mathrm{Al}_{2} \mathrm{O}_{3}$ SCALMS after $\mathrm{PDH}$ at $600{ }^{\circ} \mathrm{C}$ strongly supports this hypothesis, in particular when compared with the much smaller weight loss after $\mathrm{PDH}$ at 550 and $500{ }^{\circ} \mathrm{C}(0.29$ and 0.04 wt.-\%, respectively, Figure 8 ). The high reactivity of the coke formed on the SCALMS system in alumina after PDH at $600{ }^{\circ} \mathrm{C}$ is confirmed here by comparing the $\mathrm{CO}_{2}$ formation in the TPO experiment as a function of temperature (Figure 9

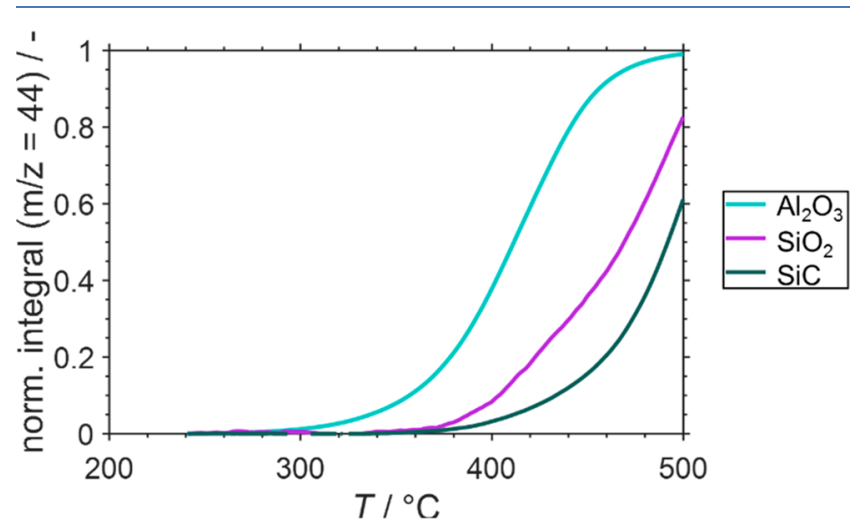

Figure 9. Normalized cumulative formation of $\mathrm{CO}_{2}$ during temperature-programmed oxidation $\left(1{ }^{\circ} \mathrm{C} \mathrm{min}^{-1}\right)$ of spent GaPt SCALMS using $\mathrm{Al}_{2} \mathrm{O}_{3}$ (blue), $\mathrm{SiO}_{2}$ (purple), and $\mathrm{SiC}$ (dark green) as support materials after propane dehydrogenation at $600{ }^{\circ} \mathrm{C}$ as monitored via high-resolution thermogravimetry coupled with mass spectrometry. Conditions: He flow $100 \mathrm{~mL}_{\mathrm{N}} \mathrm{min}^{-1}$ for TOS $<0$; He flow $79 \mathrm{~mL}_{\mathrm{N}}$ $\mathrm{min}^{-1}$ and $\mathrm{O}_{2}$ flow $21 \mathrm{~mL}_{\mathrm{N}} \mathrm{min}^{-1}$ for TOS $>0$; GHSV $30000 \mathrm{~mL}_{\mathrm{N}}$ $\mathrm{g}^{-1} \mathrm{~h}^{-1}$.

and Figure S9 in the Supporting Information). Much less reactive, graphitic coke is formed, in contrast, on the SiCsupported and, to a lower extent, on the $\mathrm{SiO}_{2}$-supported SCALMS (see Supporting Information, Figures S10-11 for Raman spectra of the spent $\mathrm{SiC}$ supported catalyst).

The results from TPO were linked with the catalytic performance data to calculate the integral selectivity of the prepared SCALMS systems toward coke using Equation 4. A clear correlation between the $\mathrm{PDH}$ reaction temperature and the selectivity for coke formation is identified on all supports (Table 4). The absolute levels of coke formation are, however,
Table 4. Integral Carbon-Based Selectivity toward Coke of the SCALMS Tested in This Study

\begin{tabular}{ccc} 
temperature & $S_{\text {coke }}$ \\
system & ${ }^{\circ} \mathrm{C}$ & $\%$ \\
$\mathrm{Ga}_{49} \mathrm{Pt} / \mathrm{Al}_{2} \mathrm{O}_{3}$ & 500 & 0.11 \\
& 550 & 0.49 \\
& 600 & 4.98 \\
$\mathrm{Ga}_{48} \mathrm{Pt} / \mathrm{SiO}_{2}$ & 500 & $<0.01$ \\
& 550 & 0.11 \\
$\mathrm{Ga}_{41} \mathrm{Pt} / \mathrm{SiC}$ & 600 & 0.49 \\
& 500 & $<0.01$ \\
& 550 & 0.17 \\
& 600 & 0.46 \\
\hline
\end{tabular}

quite different. For $\mathrm{Al}_{2} \mathrm{O}_{3}$-supported SCALMS, the selectivity for coke formation reached $4.98 \%$ at $600{ }^{\circ} \mathrm{C}$, while coke formation is under identical temperature conditions about 1 order of magnitude lower on the $\mathrm{SiC}$ - and $\mathrm{SiO}_{2}$-supported systems.

Postrun SEM Analysis and Deactivation Mechanism. After propane dehydrogenation, we selected the spent $\mathrm{SiO}_{2}$ supported SCALMS systems for further analytical studies to shed light on the deactivation mechanism during $\mathrm{PDH}$. Because of its smooth surface, the $\mathrm{SiO}_{2}$-supported system would allow for easily recognizable agglomeration phenomena that might be responsible for the observed loss of activity. In our SEM investigation, however, it was found that the droplet size distribution of the catalytic materials did not undergo major changes and was very similar for all the catalysts after $\mathrm{PDH}$ at all the temperature tested when compared to the fresh SCALMS system (Figure $10 \mathrm{a}-\mathrm{c}$ ). Therefore, more subtle effects may cause the observed decline in performance. Recently, investigation using model GaPt SCALMS on highly oriented pyrolytic graphite (HOPG) evidenced that the liquid droplet can separate into Pt-rich and Ga-rich domains as the droplet migrates over the surface of the support. ${ }^{31}$ It is possible that a similar phenomenon may also be at play on the surface of the supports tested in this study. This phase separation process may generate droplets of liquid alloy depleted in $\mathrm{Pt}$ and Pt-rich droplets that are presumably solid under the applied reaction conditions. The latter undergo irreversible deactivation via strong adhesion of carbonaceous species, while the liquid domain preserve their activity due the dynamicity of their surface

Further studies are currently ongoing in our laboratories to address these issues in more detail and to gain a better understanding of these highly dynamic catalytic systems.

\section{CONCLUSIONS}

We have demonstrated in this work a new, facile, and scalable method to prepare GaPt SCALMS by ultrasonication. This new procedure represents a very convenient alternative to the previously reported chemical route employing an air sensitive gallane complex. The GaPt SCALMS materials synthesized via this new route enabled nearly identical catalytic activity in propane dehydrogenation at benchmark conditions compared to those prepared by the chemical route despite the fact that a large part of the alloy droplets was deposited on the external surface of the applied catalyst supports. Using this ultrasonication method, GaPt SCALMS catalyst were synthesized on three different supports (alumina, silica, $\mathrm{SiC}$ ) and tested for propane dehydrogenation in the temperature range of 500- 

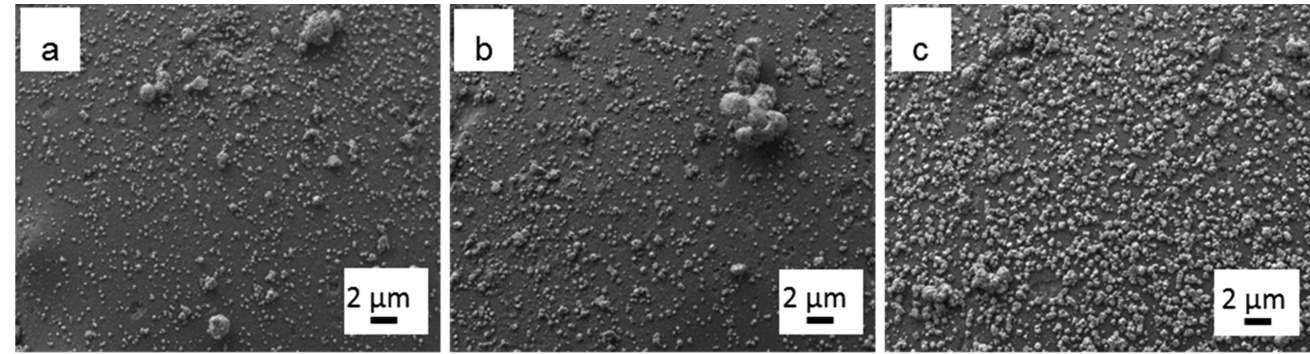

Figure 10. SEM images of GaPt catalyst supported on $\mathrm{SiO}_{2}$ (a) as prepared, (b) after $\mathrm{PDH}$ at $500{ }^{\circ} \mathrm{C}$, and (c) after $\mathrm{PDH}$ at $600{ }^{\circ} \mathrm{C}$.

$600{ }^{\circ} \mathrm{C}$. HRTGA-MS analysis of all spent catalysts confirmed that the largest part of the observed coke origins from the support. Among the prepared SCALMS materials systems, the SiC-supported materials showed the highest Pt-based productivity followed by $\mathrm{Al}_{2} \mathrm{O}_{3}$ and $\mathrm{SiO}_{2}$. The $\mathrm{SiC}$-supported SCALMS systems combine good catalytic performance with high durability, and $550{ }^{\circ} \mathrm{C}$ was identified as the best temperature for propane dehydrogenation with these systems. At these conditions, support-induced coking was low and Ptbased dehydrogenation activity was high. It is interesting to note that even at 500 and $550{ }^{\circ} \mathrm{C}$, where propene selectivity was high and hardly any coke was observed, the catalysts still showed some deactivation. This could hint for other deactivation mechanisms than coking or fouling, although we cannot rule out few atom layers of coke deposition on the catalyst as this would be below the detection limit of our HRTGA-MS.

\section{ASSOCIATED CONTENT}

\section{s) Supporting Information}

The Supporting Information is available free of charge at https://pubs.acs.org/doi/10.1021/acscatal.1c01924.

Experimental setup, $\mathrm{N}_{2}$-sorption results, relative activity vs TOS for all catalysts, cumulative productivities, post run SEM-EDX, $\mathrm{CO}_{2}$ integral signal from MS for TPO measurements, Raman spectroscopy of spent catalyst, reference experiments with pure $\mathrm{Pt}$ and $\mathrm{Ga}$ on different support, particles size distribution on as-prepared and spent catalyst (PDF)

\section{AUTHOR INFORMATION}

\section{Corresponding Author}

Peter Wasserscheid - Friedrich-Alexander-Universität Erlangen-Nürnberg (FAU), Lehrstuhl für Chemische Reaktionstechnik (CRT), 91058 Erlangen, Germany; Forschungszentrum Jülich $\mathrm{GmbH}$, Helmholtz-Institute Erlangen-Nürnberg for Renewable Energy (IEK-11), 91058 Erlangen, Germany; 이이.org/0000-0003-0413-9539; Email: peter.wasserscheid@fau.de

\section{Authors}

Narayanan Raman - Friedrich-Alexander-Universität Erlangen-Nürnberg (FAU), Lehrstuhl für Chemische Reaktionstechnik (CRT), 91058 Erlangen, Germany

Moritz Wolf - Friedrich-Alexander-Universität ErlangenNürnberg (FAU), Lehrstuhl für Chemische Reaktionstechnik (CRT), 91058 Erlangen, Germany; Forschungszentrum Jülich $\mathrm{GmbH}$, Helmholtz-Institute Erlangen-Nürnberg for Renewable Energy (IEK-11), 91058 Erlangen, Germany; (1) orcid.org/0000-0002-1326-5337
Martina Heller - Friedrich-Alexander-Universität ErlangenNürnberg (FAU), Lehrstuhl für Werkstoffwissenschaften, 91058 Erlangen, Germany

Nina Heene-Würl - Friedrich-Alexander-Universität Erlangen-Nürnberg (FAU), Lehrstuhl für Chemische Reaktionstechnik (CRT), 91058 Erlangen, Germany

Nicola Taccardi - Friedrich-Alexander-Universität ErlangenNürnberg (FAU), Lehrstuhl für Chemische Reaktionstechnik (CRT), 91058 Erlangen, Germany

Marco Haumann - Friedrich-Alexander-Universität ErlangenNürnberg (FAU), Lehrstuhl für Chemische Reaktionstechnik (CRT), 91058 Erlangen, Germany; 이이.org/00000002-3896-365X

Peter Felfer - Friedrich-Alexander-Universität ErlangenNürnberg (FAU), Lehrstuhl für Werkstoffwissenschaften, 91058 Erlangen, Germany

Complete contact information is available at:

https://pubs.acs.org/10.1021/acscatal.1c01924

\section{Notes}

The authors declare no competing financial interest.

\section{ACKNOWLEDGMENTS}

Financial support by the European Research Council is gratefully acknowledged (Project 786475: Engineering of Supported Catalytically Active Liquid Metal Solutions). Some of the authors (M.He., M.Ha., P.F., P.W.) also acknowledge support by the Deutsche Forschungsgemeinschaft (DFG, German Research Foundation) in the frame of the SFB 1452 (Project-ID 431791331). Contributions of Walter Parada to PDH catalyst testing and of Markus Brey to the coke analysis are gratefully acknowledged.

\section{REFERENCES}

(1) Taccardi, N.; Grabau, M.; Debuschewitz, J.; Distaso, M.; Brandl, M.; Hock, R.; Maier, F.; Papp, C.; Erhard, J.; Neiss, C.; Peukert, W.; Gorling, A.; Steinruck, H. P.; Wasserscheid, P. Gallium-rich Pd-Ga phases as supported liquid metal catalysts. Nat. Chem. 2017, 9, 862867.

(2) Raman, N.; Maisel, S.; Grabau, M.; Taccardi, N.; Debuschewitz, J.; Wolf, M.; Wittkamper, H.; Bauer, T.; Wu, M.; Haumann, M.; Papp, C.; Gorling, A.; Spiecker, E.; Libuda, J.; Steinruck, H. P.; Wasserscheid, P. Highly Effective Propane Dehydrogenation Using Ga-Rh Supported Catalytically Active Liquid Metal Solutions. ACS Catal. 2019, 9, 9499-9507.

(3) Bauer, T.; Maisel, S.; Blaumeiser, D.; Vecchietti, J.; Taccardi, N.; Wasserscheid, P.; Bonivardi, A.; Gorling, A.; Libuda, J. Operando DRIFTS and DFT Study of Propane Dehydrogenation over Solidand Liquid-Supported $\mathrm{Ga}_{\mathrm{x}} \mathrm{Pt}_{\mathrm{y}}$ Catalysts. ACS Catal. 2019, 9, $2842-$ 2853.

(4) Sebastian, O.; Nair, S.; Taccardi, N.; Wolf, M.; Søgaard, A.; Haumann, M.; Wasserscheid, P. Stable and Selective Dehydrogen- 
ation of Methylcyclohexane using Supported Catalytically Active Liquid Metal Solutions - $\mathrm{Ga}_{52} \mathrm{Pt} / \mathrm{SiO}_{2}$ SCALMS. ChemCatChem 2020, 12, 4533-4537.

(5) Okamoto, H.; Schlesinger, M. E.; Mueller, E. M. Ga (Gallium) binary Alloy Phase Diagrams; ASM International, 2016; Vol. 3.

(6) Yatsenko, S. P.; Sabirzyanov, N. A.; Yatsenko, A. S. Dissolution rates and solubility of some metals in liquid gallium and aluminum. $J$. Phys.: Conf. Ser. 2008, 98, 062032.

(7) Liu, J. Catalysis by Supported Single Metal Atoms. ACS Catal. 2017, 7, 34-59.

(8) Giannakakis, G.; Flytzani-Stephanopoulos, M.; Sykes, E. C. H. Single-Atom Alloys as a Reductionist Approach to the Rational Design of Heterogeneous Catalysts. Acc. Chem. Res. 2019, 52, 237247.

(9) Furukawa, S.; Komatsu, T. Intermetallic Compounds: Promising Inorganic Materials for Well-Structured and Electronically Modified Reaction Environments for Efficient Catalysis. ACS Catal. 2017, 7, 735-765.

(10) Grabau, M.; Erhard, J.; Taccardi, N.; Calderon, S. K.; Wasserscheid, P.; Gorling, A.; Steinruck, H. P.; Papp, C. Spectroscopic Observation and Molecular Dynamics Simulation of Ga Surface Segregation in Liquid Pd-Ga Alloys. Chem. - Eur. J. 2017, 23, 17701-17706.

(11) Rupprechter, G. Supported liquid metal catalysts: Popping up to the surface. Nat. Chem. 2017, 9, 833-834.

(12) Li, Q.; Sui, Z.; Zhou, X.; Zhu, Y.; Zhou, J.; Chen, D. Coke Formation on Pt-Sn/Al2O3 Catalyst in Propane Dehydrogenation: Coke Characterization and Kinetic Study. Top. Catal. 2011, 54, 888896.

(13) Iglesias-Juez, A.; Beale, A. M.; Maaijen, K.; Weng, T. C.; Glatzel, P.; Weckhuysen, B. M. A combined in situ time-resolved UVVis, Raman and high-energy resolution X-ray absorption spectroscopy study on the deactivation behavior of $\mathrm{Pt}$ and $\mathrm{PtSn}$ propane dehydrogenation catalysts under industrial reaction conditions. J. Catal. 2010, 276, 268-279.

(14) Pham, H. N.; Sattler, J. J.; Weckhuysen, B. M.; Datye, A. K. Role of $\mathrm{Sn}$ in the Regeneration of Pt/gamma- $\mathrm{Al}_{2} \mathrm{O}_{3}$ Light Alkane Dehydrogenation Catalysts. ACS Catal. 2016, 6, 2257-2264.

(15) Li, C.; Minh, C. L.; Brown, T. C. Kinetics of CO and CO2 Evolution During the Temperature-Programmed Oxidation of Coke Deposited on Cracking Catalysts. J. Catal. 1998, 178, 275-283.

(16) Nawaz, Z. Light alkane dehydrogenation to light olefin technologies: a comprehensive review. Rev. Chem. Eng. 2015, 31, 413-436.

(17) Li, L.; Wang, H.; Han, J.; Zhu, X.; Ge, Q. Balancing the Activity and Selectivity of Propane Oxidative Dehydrogenation on $\mathrm{NiOOH}$ (001) and (010). Trans. Tianjin Univ. 2020, 26, 341-351.

(18) Gambo, Y.; Adamu, S.; Abdulrasheed, A. A.; Lucky, R. A.; BaShammakh, M. S.; Hossain, M. M. Catalyst design and tuning for oxidative dehydrogenation of propane - A review. Appl. Catal., A 2021, 609, 117914.

(19) Cavani, F.; Ballarini, N.; Cericola, A. Oxidative dehydrogenation of ethane and propane: How far from commercial implementation? Catal. Today 2007, 127, 113-131.

(20) Song, H.; Kim, T.; Kang, S.; Jin, H.; Lee, K.; Yoon, H. J. GaBased Liquid Metal Micro/Nanoparticles: Recent Advances and Applications. Small 2020, 16, No. 1903391.

(21) Daeneke, T.; Khoshmanesh, K.; Mahmood, N.; de Castro, I. A.; Esrafilzadeh, D.; Barrow, S. J.; Dickey, M. D.; Kalantar-Zadeh, K. Liquid metals: fundamentals and applications in chemistry. Chem. Soc. Rev. 2018, 47, 4073-4111.

(22) Yamaguchi, A.; Mashima, Y.; Iyoda, T. Reversible Size Control of Liquid-Metal Nanoparticles under Ultrasonication. Angew. Chem., Int. Ed. 2015, 54, 12809-12813.

(23) Kumar, V. B.; Koltypin, Y.; Gedanken, A.; Porat, Z. E. Ultrasonic cavitation of molten gallium in water: entrapment of organic molecules in gallium microspheres. J. Mater. Chem. A 2014, 2, 1309-1317.
(24) Ghasemian, M. B.; Mayyas, M.; Idrus-Saidi, S. A.; Jamal, M. A.; Yang, J.; Mofarah, S. S.; Adabifiroozjaei, E.; Tang, J.; Syed, N.; O'Mullane, A. P.; Daeneke, T.; Kalantar-Zadeh, K. Self-Limiting Galvanic Growth of $\mathrm{MnO}_{2}$ Monolayers on a Liquid Metal-Applied to Photocatalysis. Adv. Funct. Mater. 2019, 29, 1901649.

(25) Minnick, D. L.; Turnaoglu, T.; Rocha, M. A.; Shiflett, M. B. Review Article: Gas and vapor sorption measurements using electronic beam balances. J. Vac. Sci. Technol., A 2018, 36, 050801.

(26) The MathWorks Inc. MATLAB, 2018b; MathWorks: Natick, MA, 2018.

(27) O'Haver, T. peakfit.m, Version 9.0, MATLAB File Exchange; MathWorks: Natick, MA, 2018.

(28) Shriver, D. F.; Shirk, A. E. Trihydrido(trimethylamine)gallium. Inorg. Synth. 1980, 17, 42-44.

(29) Wolf, M.; Raman, N.; Taccardi, N.; Horn, R.; Haumann, M.; Wasserscheid, P. Capturing spatially resolved kinetic data and coking of Ga-Pt Supported Catalytically Active Liquid Metal Solutions during propane dehydrogenation in situ. Faraday Discuss. 2021, 229, 359377.

(30) Wolf, M.; Raman, N.; Taccardi, N.; Haumann, M.; Wasserscheid, P. Coke Formation during Propane Dehydrogenation over Ga-Rh Supported Catalytically Active Liquid Metal Solutions. ChemCatChem 2020, 12, 1085-1094.

(31) Hohner, C.; Kettner, M.; Stumm, C.; Blaumeiser, D.; Wittkämper, H.; Grabau, M.; Schwarz, M.; Schuschke, C.; Lykhach, Y.; Papp, C.; Steinrück, H.-P.; Libuda, J. Pt-Ga Model SCALMS on Modified HOPG: Thermal Behavior and Stability in UHV and under Near-Ambient Conditions. J. Phys. Chem. C 2020, 124, 2562-2573. 